\title{
Sphingomonas sanxanigenens sp. nov., isolated from soil
}

\author{
Correspondence \\ Ting Ma \\ tingma@nankai.edu.cn
}

\author{
Hai-Dong Huang, ${ }^{1,2}$ Wei Wang, ${ }^{1}$ Ting Ma, ${ }^{1}$ Guo-Oiang Li, ${ }^{1}$ \\ Feng-Lai Liang ${ }^{1}$ and Ru-Lin Liu ${ }^{1}$
}
${ }^{1}$ Key Laboratory of Molecular Microbiology and Technology, Ministry of Education, College of Life Sciences, Nankai University, Tianjin 300071, PR China
${ }^{2}$ Tianjin Agricultural University, Tianjin 300384, PR China

The genus Sphingomonas was first proposed by Yabuuchi et al. (1990) and belongs to the family Sphingomonadaceae (Kosako et al., 2000). The genus description has been emended by Takeuchi et al. (1993, 2001), Yabuuchi et al. (2002) and Busse et al. (2003). Analysis of the phylogeny, polyamine patterns and fatty acid profiles of members of the genus led to the subdivision of Sphingomonas into four separate genera, i.e. Sphingomonas sensu stricto and three new genera, Sphingobium, Novosphingobium and Sphingopyxis. Strains belonging to the family Sphingomonadaceae have great potential for biotechnological applications, e.g. in the bioremediation and degradation of refractory contaminants and in the production of valuable biopolymers referred to as sphingans. Sphingans, such as gellan (S60), welan (S-130), rhamsan (S-194), S-88, heteropolysaccharide S-7, S-198, S-657, NW11, PS-P4, GS-1, I-886 and HWR1 (Matsuyama et al., 2003; Seo et al., 2004), have a similar structure, with a linear repeating tetrasaccharide that consists of glucose, glucuronic acid, rhamnose or mannose. Aqueous solutions of sphingans are very viscous or have the ability to form gels.

\footnotetext{
The GenBank/EMBL/DDBJ accession number for the 16S rRNA gene sequence of strain $\mathrm{NXO2}^{\top}$ is DQ789172.

Results of two-dimensional TLC of the polar lipids of strain $\mathrm{NXO2}^{\top}$ are available as a supplementary figure with the online version of this paper.
}

In this paper, we report the results from our polyphasic taxonomic study on a novel biopolymer-producing bacterium designated strain $\mathrm{NX02}{ }^{\mathrm{T}}$. On the basis of the physiological, chemotaxonomic and phylogenetic data, strain $\mathrm{NXO2}^{\mathrm{T}}$ represents a novel species of the genus Sphingomonas sensu stricto.

Bacteria were isolated from topsoil collected from a cornfield in Xinhe County, PR China. Isolation was performed using the standard dilution plating technique at $30{ }^{\circ} \mathrm{C}$ on NK medium (containing, per litre distilled water: $15 \mathrm{~g}$ sucrose, $5 \mathrm{~g}$ peptone, $3 \mathrm{~g}$ beef powder, $1 \mathrm{~g}$ yeast extract, $15 \mathrm{~g}$ agar; $\mathrm{pH}$ 7.0). For purification, colonies of strain $\mathrm{NX02}{ }^{\mathrm{T}}$, which had a distinct mucoid appearance, were picked and then transferred onto new plates. Strain $\mathrm{NX} 2^{\mathrm{T}}$ produces a novel extracellular biopolymer called sanxan gum, which has thickening and pseudoplastic qualities. Sanxan gum consists of carbohydrates and peptides, and the monosaccharide composition of the carbohydrate portion is similar to that of sphingans (Wang et al., 2008).

A 16S rRNA gene sequence fragment corresponding to positions 6-1540 in the Escherichia coli numbering system (Brosius et al., 1978) was amplified using the universal primers 27F (5'-GAGAGTTTGATCCTGGCTCAG-3') and 1541R (5'-AAGGAGGTGATCCAGCCGCA-3'). A phylogenetic analysis was performed using MEGA, version 3.0 
(Kumar et al., 2004), after multiple alignment of the data by CLUSTAL_X (Thompson et al., 1997). Distances (with distance options according to the Kimura-2 model) and clustering using the neighbour-joining method were determined using bootstrap percentages based on 1000 replications. The $16 \mathrm{~S}$ rRNA gene sequence of strain $\mathrm{NX}^{2} 2^{\mathrm{T}}$ was a continuous stretch of $1480 \mathrm{bp}$. A sequence similarity search of the GenBank/EMBL databases, performed using the FASTA program, revealed that strain $\mathrm{NX02}{ }^{\mathrm{T}}$ belongs to the family Sphingomonadaceae. The highest sequence similarities were found with respect to strains of established species, including Sphingomonas azotifigens NBRC $15497^{\mathrm{T}}$ (95.9\%), Sphingomonas pituitosa DSM $13101^{\mathrm{T}}(95.8 \%)$ and Sphingomonas dokdonensis KCTC $12541^{\mathrm{T}}(95.8 \%)$. The neighbour-joining phylogenetic tree (Fig. 1) showed that strain $\mathrm{NX}^{2} 2^{\mathrm{T}}$ clearly belonged to the genus Sphingomonas sensu stricto lineage, where it formed a separate branch. This branching pattern demonstrated that strain $\mathrm{NX}^{2}{ }^{\mathrm{T}}$ represents a novel species within the genus Sphingomonas sensu stricto.
Genomic DNA was isolated and purified using the method of Cashion et al. (1977). The G+C content of the genomic DNA was analysed using HPLC after enzymic degradation of the DNA into nucleosides (Mesbah et al., 1989; Tamaoka \& Komagata, 1984). DNA-DNA hybridization was carried out using the optical renaturation method (De Ley et al., 1970; Huß et al., 1983; Jahnke, 1992) with a UVVis spectrophotometer (Perkin-Elmer) under optimal hybridization conditions $\left(25{ }^{\circ} \mathrm{C}\right.$ below the melting temperature of DNA). The DNA G $+\mathrm{C}$ content was determined to be $66.4 \mathrm{~mol} \%$. The DNA-DNA relatedness between strain $\mathrm{NX}_{0} 2^{\mathrm{T}}$ and S. azotifigens NBRC $15497^{\mathrm{T}}$ was $24 \%$, i.e. below the value $(70 \%)$ considered as the threshold for the delineation of a genospecies (Stackebrandt \& Goebel, 1994).

Cell morphology was observed under light and transmission electron microscopy, using cells grown for 3 days at $30{ }^{\circ} \mathrm{C}$ (Fig. 2). All other physiological and biochemical tests were performed as described by Li et al. (2004) and Lebuhn

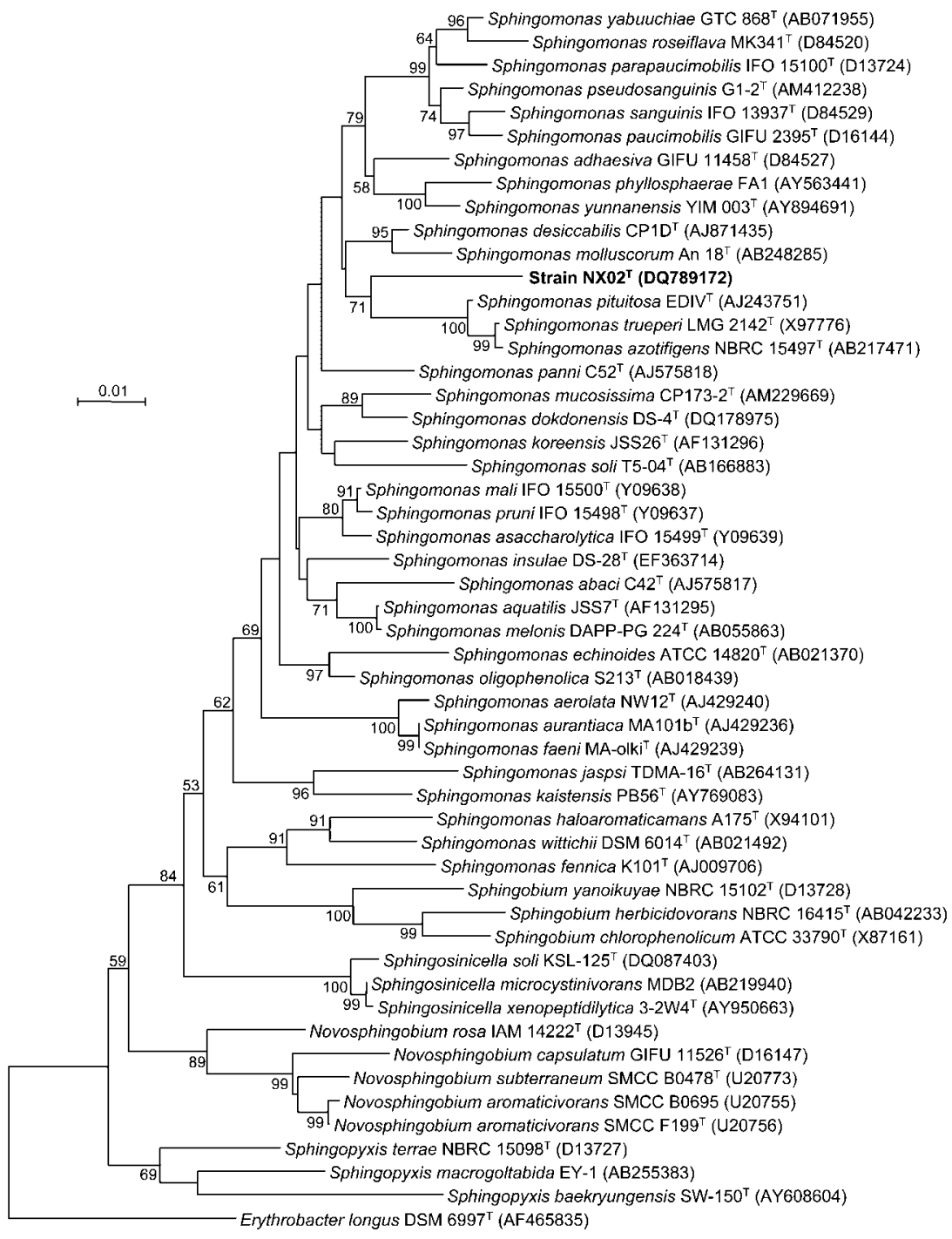

Fig. 1. Neighbour-joining phylogenetic tree, based on 16S rRNA gene sequences, showing the relationships between strain $\mathrm{NXO2}^{\top}$ and related taxa. Bootstrap percentages (based on 1000 replicates) are shown at nodes: only values greater than $50 \%$ are shown. The sequence of Erythrobacter longus DSM $6997^{\top}$ was used as the outgroup. Bar, $1 \%$ sequence divergence. 


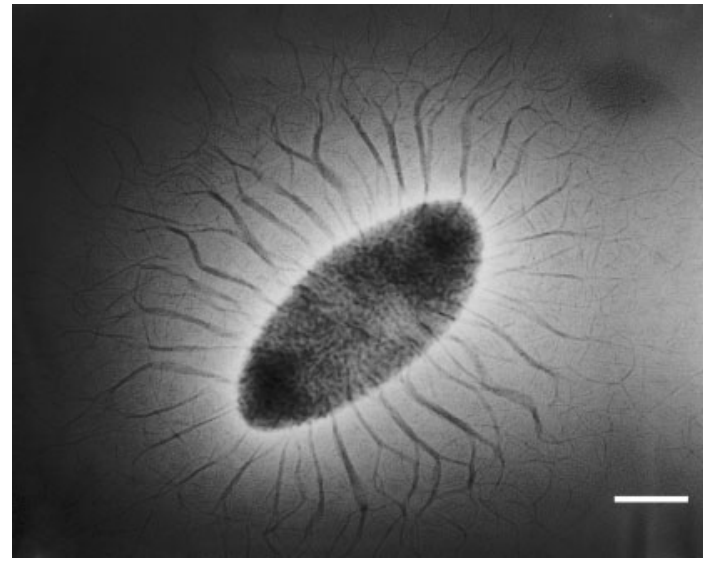

Fig. 2. Transmission electron micrograph of a cell of strain $\mathrm{NXO}^{\top}$. Bar, $500 \mathrm{~nm}$.

et al. (2000). Growth occurred at $4-40{ }^{\circ} \mathrm{C}$ and at $\mathrm{pH} 4.0$ 8.5 , with optima at $28-30{ }^{\circ} \mathrm{C}$ and $\mathrm{pH}$ 7.0-7.5. Growth occurred in the presence of $0-1.2 \%(\mathrm{w} / \mathrm{v}) \mathrm{NaCl}$, with optimal growth at $0-0.05 \%(\mathrm{w} / \mathrm{v})$. Phenotypic features of strain $\mathrm{NX}^{\mathrm{T}}$ and phylogenetically related species are shown in Table 1. Strain $\mathrm{NXO2}^{\mathrm{T}}$ could be distinguished from its close relatives on the basis of a combination of phenotypic features. Strain $\mathrm{NX02^{ \textrm {T } }}$ was similar to Sphingomonas desiccabilis DSM $16792^{\mathrm{T}}$ in being positive for nitrate reduction, but it differed with regard to the oxidase reaction, the hydrolysis of starch and aesculin and the substrate-assimilation profile. Oxidase activity is absent in strain $\mathrm{NXO2}^{\mathrm{T}}$ and S. pituitosa DSM $13101^{\mathrm{T}}$. This is an unusual biochemical trait that has been reported for only a few sphingan-producing strains of the genus Sphingomonas (Yabuuchi et al., 1990; Pollock, 1993).

Chemotaxonomic analyses were performed as follows. Respiratory quinones and polar lipids were determined as described by Tindall (1990a, b) and Altenburger et al. (1996), respectively, and were carried out by Dr B. J. Tindall and the Identification Service of the Deutsche Sammlung von Mikroorganismen und Zellkulturen (Braunschweig, Germany). Polyamines were extracted as described by Busse \& Auling (1988) and analysed according to Busse et al. (1997). Fatty acid analysis was performed using the standard method of Sasser (1990): the results were compared with the database of fatty acids in the Sherlock Microbial Identification System (MIDI). The quinone system of strain $\mathrm{NX} 02^{\mathrm{T}}$ consisted of Q-10 (78\%) and Q-11 (22\%). The polar lipids detected were sphingoglycolipid, phosphatidylcholine, phosphatidylglycerol, diphosphatidylglycerol, phosphatidylethanolamine, phosphatidylmonomethylethanolamine, phosphatidyldimethylethanolamine and an unidentified glycolipid (the twodimensional thin-layer chromatogram is presented in Supplementary Fig. S1, available in IJSEM Online). The
Table 1. Phenotypic characteristics of strain $\mathrm{NXO} 2^{\top}$ and the type strains of related Sphingomonas species

Strains: $1, \mathrm{NX}^{\mathrm{T}}{ }^{\mathrm{T}}$ (data from this study); 2, S. pituitosa DSM $13101^{\mathrm{T}}$ (Denner et al., 2001); 3, S. trueperi ATCC $12417^{\mathrm{T}}$ (Kämpfer et al., 1997; Denner et al., 2001); 4, S. azotifigens NBRC $15497^{\mathrm{T}}$ (Xie \& Yokota, 2006); 5, S. dokdonensis KCTC $12541^{\mathrm{T}}$ (Yoon et al., 2006); 6, S. desiccabilis DSM $16792^{\mathrm{T}}$ (Reddy \& Garcia-Pichel, 2007); 7, S. molluscorum CIP $109223^{\mathrm{T}}$ (Romanenko et al., 2007). +, Positive; -, negative; ND, no data available. All of the strains were positive for catalase activity and negative for indole production and assimilation of citrate.

\begin{tabular}{|lccccccc|}
\hline Characteristic & $\mathbf{1}$ & $\mathbf{2}$ & $\mathbf{3}$ & $\mathbf{4}$ & $\mathbf{5}$ & $\mathbf{6}$ & $\mathbf{7}$ \\
\hline Oxidase & - & - & + & + & + & + & + \\
Nitrate reduction & + & - & - & - & - & + & - \\
Hydrolysis of: & & & & & & & \\
$\quad$ Starch & - & - & + & + & + & + & - \\
$\quad$ Aesculin & + & + & - & + & + & - & + \\
Gelatin & + & - & - & - & + & + & - \\
Assimilation of: & & & & & & & \\
$\quad$ Acetate & - & + & + & + & + & - & $\mathrm{ND}$ \\
L-Arabinose & + & + & + & + & - & + & + \\
L-Aspartate & - & - & + & + & $\mathrm{ND}$ & - & $\mathrm{ND}$ \\
$\quad$ D-Fructose & - & - & + & + & - & - & $\mathrm{ND}$ \\
D-Glucose & + & + & + & + & - & + & + \\
L-Glutamic acid & - & $\mathrm{ND}$ & + & + & - & - & $\mathrm{ND}$ \\
Lactose & - & + & + & + & $\mathrm{ND}$ & - & + \\
$\quad$ Maltose & - & + & + & + & - & + & + \\
DNA G+C content & 66.4 & 64.5 & 65.6 & $66.0-$ & 66.9 & $\mathrm{ND}$ & 68.3 \\
$\quad$ (mol\%) & & & & $68.0^{*}$ & & & \\
\hline
\end{tabular}

${ }^{\star}$ Range of values for three strains, including the type strain.

polyamine patterns of strain $\mathrm{NX02}{ }^{\mathrm{T}}$ showed a predominance of sym-homospermidine and trace amounts of spermidine. The presence of 2-hydroxy fatty acids and the absence of 3-hydroxy fatty acids are common characteristics of members of the family Sphingomonadaceae (Busse et al., 1999; Takeuchi et al., 2001). The cellular fatty acids of strain NX02 ${ }^{\mathrm{T}}$ mainly comprise $\mathrm{C}_{18: 1} \omega 7 c(53.8 \%), \mathrm{C}_{16: 0}(15.1 \%)$ and $\mathrm{C}_{14: 0} 2-\mathrm{OH}(12.0 \%)$. This profile is consistent with that of the genus Sphingomonas sensu stricto (Busse et al., 1999). However, strain $\mathrm{NX02}{ }^{\mathrm{T}}$ could be easily distinguished from its closest phylogenetic neighbours, both qualitatively and quantitatively, with regard to certain fatty acids and by the higher levels of $\mathrm{C}_{18: 1} \omega 7 c$ (Table 2).

On the basis of morphological and chemotaxonomic data and the results of the 16S rRNA gene sequence analysis,

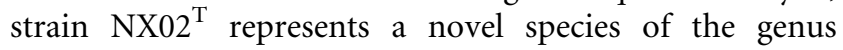
Sphingomonas, for which the name Sphingomonas sanxanigenens sp. nov. is proposed.

\section{Description of Sphingomonas sanxanigenens sp. nov.}

Sphingomonas sanxanigenens [san.xa.ni.ge'nens. N.L. n. sanxanum sanxan gum (an extracellular biopolymer); L. 
Table 2. Cellular fatty acid profiles of strain $\mathrm{NXO2}^{\top}$ and the type strains of related Sphingomonas species

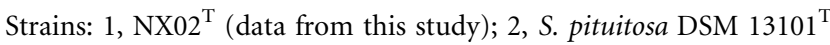
(Denner et al., 2001); 3, S. trueperi ATCC $12417^{\mathrm{T}}$ (Kämpfer et al., 1997); 4, S. azotifigens NBRC $15497^{\mathrm{T}}$ (Xie \& Yokota, 2006); 5, S. dokdonensis KCTC $12541^{\mathrm{T}}$ (Yoon et al., 2006); 6, S. desiccabilis DSM $16792^{\mathrm{T}}$ (Reddy \& Garcia-Pichel, 2007); 7, S. molluscorum CIP $109223^{\mathrm{T}}$ (Romanenko et al., 2007). Values are percentages of total fatty acids; - , not detected/not reported.

\begin{tabular}{|c|c|c|c|c|c|c|c|}
\hline Fatty acid & 1 & 2 & 3 & 4 & 5 & 6 & 7 \\
\hline $\mathrm{C}_{14: 0}$ & 0.9 & - & - & 2.6 & 0.8 & 0.8 & - \\
\hline $\mathrm{C}_{15: 0}$ & - & 2.6 & - & - & - & 0.9 & 1.7 \\
\hline $\mathrm{C}_{16: 0}$ & 15.1 & 11.5 & 9.8 & 24.5 & 19.0 & 13.4 & 24.0 \\
\hline $\mathrm{C}_{16: 1} \omega 5 c$ & 1.6 & - & - & - & 1.3 & 1.6 & - \\
\hline $\begin{array}{l}\mathrm{C}_{16: 1} \omega 7 c / \text { iso }-\mathrm{C}_{15: 0} \\
2-\mathrm{OH}\end{array}$ & 8.3 & 2.1 & - & 1.2 & 14.8 & 18.1 & - \\
\hline $\mathrm{C}_{17: 1} \omega 6 c$ & 1.0 & 13.0 & 13.6 & 1.4 & - & 6.8 & - \\
\hline $\mathrm{C}_{18: 1} \omega 5 c$ & - & - & 4.0 & 1.2 & - & 3.7 & - \\
\hline $\mathrm{C}_{18: 1} \omega 7 c$ & 53.8 & $54.2^{\star}$ & $64.2^{*}$ & 44.7 & 45.7 & 37.8 & $17.7 \dagger$ \\
\hline $\mathrm{C}_{14: 0} 2-\mathrm{OH}$ & 12.0 & 14.2 & 6.7 & 13.3 & 12.1 & 4.5 & 12.8 \\
\hline 11-Methyl $\mathrm{C}_{18: 1} \omega 7 c$ & 7.3 & - & - & 10.9 & 6.3 & - & - \\
\hline
\end{tabular}

${ }^{*}$ Reported as summed feature 7 (one or more of $\mathrm{C}_{18: 1} \omega 7 c, \mathrm{C}_{18: 1} \omega 9 t$ and $\left.\mathrm{C}_{18: 1} \omega 12 t\right)$.

$\dagger$ Also reported to contain $16.5 \% \mathrm{C}_{18: 1} \omega 9$.

part. adj. genens (from L. v. genere to produce) producing; N.L. part. adj. sanxanigenens sanxan gum-producing].

Cells are rod-shaped, $0.6-0.9 \mu \mathrm{m}$ wide and $1.5-2.0 \mu \mathrm{m}$ long and do not exhibit flagella. After 6 days incubation at $30{ }^{\circ} \mathrm{C}$, colonies on NK medium are white, circular, convex, mucoid and 5-6 $\mathrm{mm}$ in diameter. Optimum growth occurs at $\mathrm{pH} 7.0-7.5,28-30{ }^{\circ} \mathrm{C}$ and $0-0.05 \% \mathrm{NaCl}$. Cells are Gram-negative and non-spore-forming. Metabolism is non-fermentative. Positive for catalase and for nitrate reduction. Negative for oxidase, urease and for indole and $\mathrm{H}_{2} \mathrm{~S}$ production and in the methyl red and VogesProskauer tests. Positive for acid coagulation reaction in litmus milk. Hydrolyses aesculin and gelatin but not starch. The following are used as substrates for growth: Larabinose, cellobiose, dextrin, D-galactose, gentiobiose, $\alpha$ D-glucose, D-mannose, melibiose, pyruvic acid methyl ester, D-glucuronic acid, $\beta$-hydroxybutyric acid, sebacic acid, glycyl L-glutamic acid, raffinose, sucrose, trehalose, bromosuccinic acid, succinamic acid and urocanic acid. The major respiratory lipoquinone is Q-10. The predominant polyamine is sym-homospermidine. The polar lipids contain sphingoglycolipid, phosphatidylcholine, phosphatidylglycerol, diphosphatidylglycerol, phosphatidylethanolamine, phosphatidylmonomethylethanolamine, phosphatidyldimethylethanolamine and an unidentified glycolipid. The cellular fatty acids mainly comprise $\mathrm{C}_{18: 1} \omega 7 c, \mathrm{C}_{16: 0}$ and $\mathrm{C}_{14: 0} 2-\mathrm{OH}$. The DNA G $+\mathrm{C}$ content of the type strain is $66.4 \mathrm{~mol} \%$.
The type strain, NX02 $2^{\mathrm{T}} \quad\left(=\mathrm{DSM} 19645^{\mathrm{T}}=\mathrm{CGMCC}\right.$ $\left.1.6417^{\mathrm{T}}\right)$, was isolated from soil.

\section{Acknowledgements}

The authors are grateful to Dr J. P. Euzéby for his help with the nomenclature. We thank Mr Y. G. Zhou for his help with deposition of the novel strain. This work was supported by the RFDP of China (no. 20070055049).

\section{References}

Altenburger, P., Kämpfer, P., Makristathis, A., Lubitz, W. \& Busse, H.-J. (1996). Classification of bacteria isolated from a medieval wall painting. J Biotechnol 47, 39-52.

Brosius, J., Palmer, J. L., Kennedy, J. P. \& Noller, H. F. (1978). Complete nucleotide sequence of a $16 \mathrm{~S}$ ribosomal RNA gene from Escherichia coli. Proc Natl Acad Sci U S A 75, 4801-4805.

Busse, H.-J. \& Auling, G. (1988). Polyamine pattern as a chemotaxonomic marker within the Proteobacteria. Syst Appl Microbiol 11, 1-8.

Busse, H.-J., Bunka, S., Hensel, A. \& Lubitz, W. (1997). Discrimination of members of the family Pasteurellaceae based on polyamine patterns. Int J Syst Bacteriol 47, 698-708.

Busse, H.-J., Kämpfer, P. \& Denner, E. B. M. (1999). Chemotaxonomic characterisation of Sphingomonas. J Ind Microbiol Biotechnol 23, 242-251.

Busse, H.-J., Denner, E. B. M., Buczolits, S., Salkinoja-Salonen, M., Bennasar, A. \& Kämpfer, P. (2003). Sphingomonas aurantiaca sp. nov., Sphingomonas aerolata sp. nov. and Sphingomonas faeni sp. nov., air- and dustborne and Antarctic, orange-pigmented, psychrotolerant bacteria, and emended description of the genus Sphingomonas. Int $J$ Syst Evol Microbiol 53, 1253-1260.

Cashion, P., Holder-Franklin, M. A., McCully, J. \& Franklin, M. (1977). A rapid method for the base ratio determination of bacterial DNA. Anal Biochem 81, 461-466.

De Ley, J., Cattoir, H. \& Reynaerts, A. (1970). The quantitative measurement of DNA hybridization from renaturation rates. Eur $J$ Biochem 12, 133-142.

Denner, E. B. M., Paukner, S., Kämpfer, P., Moore, E. R. B., Abraham, W.-R., Busse, H.-J., Wanner, G. \& Lubitz, W. (2001). Sphingomonas pituitosa sp. nov., an exopolysaccharide-producing bacterium that secretes an unusual type of sphingan. Int J Syst Evol Microbiol 51, 827-841.

Huß, V. A. R., Festl, H. \& Schleifer, K. H. (1983). Studies on the spectrophotometric determination of DNA hybridization from renaturation rates. Syst Appl Microbiol 4, 184-192.

Jahnke, K. D. (1992). BASIC computer program for evaluation of spectroscopic DNA renaturation data from Gilford System 2600 spectrophotometer on a PC/XT/AT type personal computer. J Microbiol Methods 15, 61-73.

Kämpfer, P., Denner, E. B. M., Meyer, S., Moore, E. R. B. \& Busse, H.-J. (1997). Classification of "Pseudomonas azotocolligans" Anderson 1955, 132, in the genus Sphingomonas as Sphingomonas trueperi sp. nov. Int J Syst Bacteriol 47, 577-583.

Kosako, Y., Yabuuchi, E., Naka, T., Fujiwara, N. \& Kobayashi, K. (2000). Proposal of Sphingomonadaceae fam. nov., consisting of Sphingomonas Yabuuchi et al. 1990, Erythrobacter Shiba and Shimidu 1982, Erythromicrobium Yurkov et al. 1994, Porphyrobacter Fuerst et al. 1993, Zymomonas Kluyver and van Niel 1936, and Sandaracinobacter Yurkov et al. 1997, with the type genus Sphingomonas Yabuuchi et al. 1990. Microbiol Immunol 44, 563-575. 
Kumar, S., Tamura, K. \& Nei, M. (2004). MEGA3: integrated software for molecular evolutionary genetics analysis and sequence alignment. Brief Bioinform 5, 150-163.

Lebuhn, M., Achouak, W., Schloter, M., Berge, O., Meier, H., Barakat, M., Hartmann, A. \& Heulin, T. (2000). Taxonomic characterization of Ochrobactrum sp. isolates from soil samples and wheat roots, and description of Ochrobactrum tritici sp. nov. and Ochrobactrum grignonense sp. nov. Int J Syst Evol Microbiol 50, 2207-2223.

Li, W. J., Zhang, Y. Q., Park, D. J., Li, C. T., Xu, L. H., Kim, C. J. \& Jiang, C. L. (2004). Duganella violaceinigra sp. nov., a novel mesophilic bacterium isolated from forest soil. Int J Syst Evol Microbiol 54, 18111814.

Matsuyama, H., Kamesaki, T., Sasaki, R., Minami, H. \& Yumoto, I. (2003). Production of two types of exopolysaccharide by Novosphingobium rosa. J Biosci Bioeng 95, 152-156.

Mesbah, M., Premachandran, U. \& Whitman, W. B. (1989). Precise measurement of the $\mathrm{G}+\mathrm{C}$ content of deoxyribonucleic acid by highperformance liquid chromatography. Int J Syst Bacteriol 39, 159-167.

Pollock, T. J. (1993). Gellan-related polysaccharides and the genus Sphingomonas. J Gen Microbiol 139, 1939-1945.

Reddy, G. S. N. \& Garcia-Pichel, F. (2007). Sphingomonas mucosissima sp. nov. and Sphingomonas desiccabilis sp. nov., from biological soil crusts in the Colorado Plateau, USA. Int J Syst Evol Microbiol 57, 1028-1034.

Romanenko, L. A., Uchino, M., Frolova, G. M., Tanaka, N., Kalinovskaya, N. I., Latyshev, N. \& Mikhailov, V. V. (2007). Sphingomonas molluscorum sp. nov., a novel marine isolate with antimicrobial activity. Int J Syst Evol Microbiol 57, 358-363.

Sasser, M. (1990). Identification of bacteria by gas chromatography of cellular fatty acids. USFCC Newsl 20, 16.

Seo, E. J., Yoo, S. H., Oh, K. W., Cha, J., Lee, H. G. \& Park, C. S. (2004). Isolation of an exopolysaccharide-producing bacterium, Sphingomonas sp. CS101, which forms an unusual type of sphingan. Biosci Biotechnol Biochem 68, 1146-1148.

Stackebrandt, E. \& Goebel, B. M. (1994). Taxonomic note: a place for DNA-DNA reassociation and $16 \mathrm{~S}$ rRNA sequence analysis in the present species definition in bacteriology. Int J Syst Bacteriol 44, 846849.

Takeuchi, M., Kawai, F., Shimada, Y. \& Yokota, A. (1993). Taxonomic study of polyethylene glycerol-utilizing bacteria: emended description of the genus Sphingomonas and new descriptions of Sphingomonas macrogoltabidus sp. nov., Sphingomonas sanguis sp. nov. and Sphingomonas terrae sp. nov. Syst Appl Microbiol 16, 227-238.

Takeuchi, M., Hamana, K. \& Hiraishi, A. (2001). Proposal of the genus Sphingomonas sensu stricto and three new genera, Sphingobium, Novosphingobium and Sphingopyxis, on the basis of phylogenetic and chemotaxonomic analyses. Int J Syst Evol Microbiol 51, 1405-1417.

Tamaoka, J. \& Komagata, K. (1984). Determination of DNA base composition by reversed-phase high-performance liquid chromatography. FEMS Microbiol Lett 25, 125-128.

Thompson, J. D., Gibson, T. J., Plewniak, F., Jeanmougin, F. \& Higgins, D. G. (1997). The CLUSTAL_X windows interface: flexible strategies for multiple sequence alignment aided by quality analysis tools. Nucleic Acids Res 25, 4876-4882.

Tindall, B. J. (1990a). Lipid composition of Halobacterium lacusprofundi. FEMS Microbiol Lett 66, 199-202.

Tindall, B. J. (1990b). A comparative study of the lipid composition of Halobacterium saccharovorum from various sources. Syst Appl Microbiol 13, 128-130.

Wang, W., Huang, H. D., Zhang, Y., Ma, T., Zhang, G. P., Liang, F. L. \& Liu, R. L. (2008). Rheological and gelling properties of a novel biopolymer. Microbiology (Beijing) 35, 866-871 (in Chinese).

Xie, C. H. \& Yokota, A. (2006). Sphingomonas azotifigens sp. nov., a nitrogen-fixing bacterium isolated from the roots of Oryza sativa. Int J Syst Evol Microbiol 56, 889-893.

Yabuuchi, E., Yano, I., Oyaizu, H., Hashimoto, Y., Ezaki, T. \& Yamamoto, H. (1990). Proposals of Sphingomonas paucimobilis gen. nov. and comb. nov., Sphingomonas parapaucimobilis sp. nov., Sphingomonas yanoikuyae sp. nov., Sphingomonas adhaesiva sp. nov., Sphingomonas capsulata comb. nov., and two genospecies of the genus Sphingomonas. Microbiol Immunol 34, 99-119.

Yabuuchi, E., Kosako, Y., Fujiwara, N., Naka, T., Matsunaga, I., Ogura, H. \& Kobayashi, K. (2002). Emendation of the genus Sphingomonas Yabuuchi et al. 1990 and junior objective synonymy of the species of three genera, Sphingobium, Novosphingobium and Sphingopyxis, in conjunction with Blastomonas ursincola. Int J Syst Evol Microbiol 52, 1485-1496.

Yoon, J. H., Lee, M. H., Kang, S. J., Lee, S. Y. \& Oh, T. K. (2006). Sphingomonas dokdonensis sp. nov., isolated from soil. Int J Syst Evol Microbiol 56, 2165-2169. 